\title{
PROKSIMAT DAN TOTAL BAKTERI IKAN LAYANG (Decapterus sp.) ASIN KERING HASIL PENGERINGAN MENGGUNAKAN PENGERING SURYA TERTUTUP
}

\section{Proximate and Bacterial of Dry Salted Indian Scad (Decapterus sp.) Produced by Using Closed Sun Dryer}

\author{
Raja B. D. Sormin ${ }^{* 1)}$, Edir Lokollo'1), Febe F. Gaspersz ${ }^{1)}$ dan Vicko F. J. Tahalea ${ }^{2)}$ \\ 1)Jurusan Teknologi Hasil Perikanan, Fakultas Perikanan dan ilmu Kelautan \\ Universitas Pattimura \\ ${ }^{2)}$ Alumni Jurusan Teknologi Hasil Perikanan, Fakultas Perikanan dan ilmu Kelautan \\ Universitas Pattimura
}

Koresponden: sormindolok@gmail.com

\begin{abstract}
ABSTRAK
Penelitian ini bertujuan untuk mempelajari nilai proksimat dan kandungan bakteri ikan layang (Decapterus sp.) asin kering yang dikeringkan menggunakan alat pengering tenaga matahari sistem tertutup. Metode penelitian adalah penyiangan ikan layang dalam bentuk butterfly kemudian dicuci menggunakan air yang mengalir dan direndam dalam larutan garam 15\% selama 30 menit. Metode pengeringan menggunakan alat pengering matahari sistem tertutup, berbentuk lemari pengering dengan mempunyai 3 buah rak pengering, Rak 1, Rak 2 dan Rak 3 dimulai dari bawah. Ikan layang asin kering dianalisa proksimat yang terdiri dari kadar air, kadar abu, kadar lemak, dan kadar protein, serta uji bakteri menggunakan Total Plate Count (TPC). Hasil penelitian menunjukkan bahwa nilai proksimat pada Rak 1, Rak2, dan Rak 3 berturut-turut adalah adalah kadar air 25,58\%, ; 20,39\%, dan 17,80\%; kadar abu 9,64\%, 9,69\% dan 7,71\%., kadar lemak 8,08\%, 11,40\%, dan 15,16\%, dan kadar protein 53,73\% , 58,10\%, dan 59,11\%. Sementara nilai Total Plate Count (TPC) ikan layang (Decapterus sp.) asin kering pada Rak 1, Rak2, dan Rak 3 berturut-turut adalah 2,73 $\log \times \mathrm{CFU} / \mathrm{g}$ atau 5,4 x $10^{2} \mathrm{CFU} / \mathrm{g}$, 2,74 logx CFU/g atau 5,5 x $10^{2} \mathrm{CFU} / \mathrm{g}$, dan 2,74 $\operatorname{logx} \mathrm{CFU} / \mathrm{gr}$ atau 5,9 x $10^{2} \mathrm{CFU} / \mathrm{gr}$. Tempat terbaik untuk meletakkan ikan pada alat pengering adalah pada Rak 3, hal ini ditunukkan oleh kadar air yang rendah. Nilai TPC ikan layang (Decapterus $s p$ ) asin kering hasil pengeringan menggunakan sistim pengering tertutup menunjukkan hasil yang baik, dimana nilai TPC masih berada pada batas nilai yang di syaratkan oleh SNI.
\end{abstract}

Kata kunci: bakteri, Ikan layang, pengeringan, proksimat, sistem tertutup. 


\section{ABSTRACT}

This study aims to determine the proximate and total bacterial of dry salted scad fish (Decapterus sp.) dried using a closed solar drying sistem. The research method begins with fish weed in 'butterfly' then washed using flowed water and immersed in $15 \%$ salt solution for 30 minutes. The drying method was a closed sun drying cabinet sistem, with 3 drying racks named Rack 1, Rack 2 and Rack 3 starting from the bottom. The dried salted fish was analyzed its proximate consisting of moisture content, ash content, fat content and protein content, as well as bacterial tests using Total Plate Count (TPC). The results showed that the proximate values on Rack 1, Rak2, and Rack 3 were water content of $25.58 \%, 20.39 \%$, and $17.80 \%$ respectively; ash content of $9.64 \%, 9.69 \%$ and $7.71 \%$ respectively, fat content $8.08 \%, 11.40 \%$ and $15.16 \%$, respectively and protein content $53.73 \%, 58.10 \%$, and $59.11 \%$. respectively. Meanwhile, the total plate count (TPC) value of dried salted layang fish (Decapterus sp) on Rack 1, Rak2, and Rack 3 was $2.73 \log$ x CFU / g or 5.4 x $102 \mathrm{CFU} / \mathrm{g}$, 2.74. $\log \mathrm{CFU} / \mathrm{g}$ or $5.5 \mathrm{x} 102 \mathrm{CFU} / \mathrm{g}$, and $2.74 \operatorname{logx} \mathrm{CFU} / \mathrm{gr}$ or $5.9 \times 102 \mathrm{CFU} / \mathrm{gr}$, respectively. The best place to put fish in the dryer is on Rack 3 as this is indicated by the low moisture content. The TPC value was still within the value limit required by the SNI.

Key words : bacterial, closed sistem, drying, Indian scad, proximate

\section{PENDAHULUAN}

Ikan layang (Decapterus sp.) termasuk komoditi perikanan pelagis yang penting di Indonesia dan biasanya hidup bergerombol dengan ikan lain seperti lemuru (Sardinella sirm), tembang (Sardinella fimbriala, $S$. perforala), kembung (Rastrelliger kanaguaa. R. brachysoma), selar (Canax sp.), dan ekor kuning (Caerio sp.). Di perairan Indonesia terdapat 5 jenis yang umum dijumpai yaitu Decapterus lajang, D. russelli, D. macrosoma. D. kurroides, dan D. maruadsi. Kelima jenis tersebut banyak terdapat di perairan Maluku (1). Ikan layang ini hampir dijumpai sepanjang musim dan dalam jumlah yang banyak.

Ikan merupakan bahan makanan bernutrisi yang mudah mengalami kebusukan. Hal ini karena daging ikan segar mengandung sampai $80 \%$ air dan merupakan bahan yang sangat mudah busuk dan mempunyai masa simpan yang pendek apabila dibiarkan tanpa penanganan (2). Untuk menghindari terjadinya kerusakan ikan maka segera setelah ditangkap ikan harus ditangani secepatnya. Penanganan ikan yang biasa dilakukan adalah dengan pendinginan. Namun pendinginan mempunyai kelemahan yaitu membutuhkan biaya yang besar untuk membeli es atau alat pendingin dan daya tahan ikan dingin pun hanya sekitar 8 hari.

Berdasarkan hal tersebut maka dilakukanlah pengeringan, dengan tujuan menurunkan kandungan air ikan ke komposisi yang diinginkan. Pengeringan adalah teknologi pengolahan yang sudah lama dilakukan. Secara tradisional ikan dikeringkan dibawah sinar matahari yang disebut dengan open sun drying. Metode ini membutuhkan lahan yang luas dan sangat tergantung kepada cuaca. Metode ini rentan terhadap binatang peliharaan, binatang pengerat, lalat dan kotoran lain di sekitar tempat pengeringan sehingga menyebabkan kebusukan baik oleh binatang-binatang dimaksud maupun oleh bakteri (3). Pengeringan adalah salah satu metode yang sangat penting dalam pengawetan ikan, dan sudah dipraktekkan sejak lama dalam proses pengolahan ikan, karena membutuhkan energi yang murah yaitu sinar matahari (4). Pengeringan secara konvensional menggunakan udara panas adalah 
metode yang biasa digunakan (5). Penelitian ini bertujuan untuk mempelajari nilai proksimat dan kandungan bakteri ikan layang asin kering yang dikeringkan menggunakan alat pengering tenaga matahari sistem tertutup.

\section{METODE PENELITIAN}

\subsection{Bahan dan alat}

Bahan-bahan yang digunakan dalam penelitian ini adalah Ikan Layang dari desa Waai, Kecamatan Salahutu Kabupaen Maluku Tengah, larutan garam 15\% dan bahan-bahan kimia lainnya untuk proses analisis.

Alat-alat yang digunakan dalam Penelitian ini adalah Baskom, Timbangan Analitik, Talenan, Pisau, Ember, Alat Pengering sinar matahari tertutup (Solar Dryer), Thermometer, dan beberapa alat laboratorium lainnya untuk keperluan analisa

\subsection{Prosedur Kerja}

Sampel ikan layang (Decapterus sp.) didapatkan dari nelayan di Desa Waai, kemudian di bawah ke Laboratorium Teknologi Hasil Perikanan, Fakultas
Perikanan dan Ilmu Kelautan Universitas Pattimura Ambon dengan menggunakan coolbox.

Ikan layang disiangi dalam bentuk butterfly kemudian dicuci menggunakan air yang mengalir. Selanjutnya diambil sebagian untuk di uji kadar protein, kadar lemak, kadar air, kadar abu, kadar dan karbohidrat, sebagian lagi direndam dalam larutan garam 15\% selama 30 menit. Setelah direndam, ikan ditiriskan kemudian dikeringkan dengan menggunakan alat pengering matahari sistem tertutup (Gambar 1), dimana alat pengering sistem tertutup ini berbentuk lemari pengering dengan mempunyai 3 buah rak pengering yang disebut Rak 1, Rak 2 dan Rak 3 dimulai dari bawah. Pengeringan ikan layang dilakukan selama lima hari. Setelah ikan kering dilakukan analisa proksimat yang teridi dari kadar protein, kadar lemak, kadar air, dan kadar abu, serta analisis Total Plate Count (TPC).

\subsection{Parameter Uji}

Parameter yang di analisis meliputi: Proksimat (kadar air, kadar abu, kadar lemak, kadar protein), dan Nilai TPC.

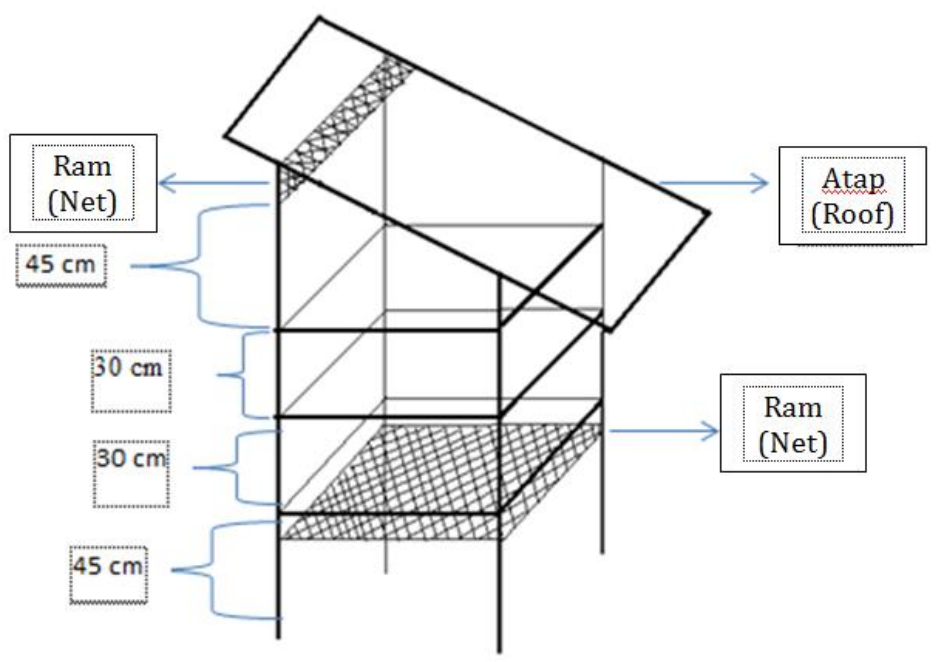

Gambar 1. Sketsa Alat pengering matahari tertutup.

Fig. 1. Sketch of closed sun dryer 


\subsection{Analisis Kadar Air}

Analisis kadar air dilakukan dengan menggunakan metode oven [6]. Prinsipnya adalah menguapkan molekul air $\left(\mathrm{H}_{2} \mathrm{O}\right)$ bebas yang ada dalam sampel kemudian sampel ditimbang sampai didapat bobot konstan yang diasumsikan semua air yang terkandung dalam sampel sudah diuapkan. Selisih bobot sebelum dan sesudah pengeringan merupakan banyaknya air yang diuapkan. Prosedur analisis kadar air sebagai berikut: cawan yang akan digunakan dioven terlebih dahulu selama 30 menit pada suhu 100-105 ${ }^{\circ} \mathrm{C}$, kemudian didinginkan dalam desikator untuk menghilangkan uap air dan ditimbang (A). Sampel ditimbang sebanyak 2 gr dalam cawan yang sudah dikeringkan (B) kemudian dioven pada suhu $100-105{ }^{\circ} \mathrm{C}$ selama 6 jam lalu didinginkan dalam desikator selama 30 menit dan ditimbang (C). Tahap ini diulangi hingga dicapai bobot yang konstan. Kadar air dihitung dengan rumus:

$$
\% \text { Kadar air }=\frac{B-C}{B-A} \times 100 \%
$$

Keterangan :

A : berat cawan kosong dinyatakan dalam gram

B : berat cawan + sampel awal dinyatakan dalam gram

$\mathrm{C}$ : berat cawan + sampel kering dinyatakan dalam gram

\subsection{Analisis Kadar Abu}

Analisis kadar abu dilakukan menggunakan metode oven [6]. Prinsipnya adalah pembakaran atau pengabuan bahanbahan organik yang diuraikan menjadi air $\left(\mathrm{H}_{2} \mathrm{O}\right)$ dan karbondioksida $\left(\mathrm{CO}_{2}\right)$ tetapi zat anorganik tidak terbakar. Zat anorganik ini disebut abu. Prosedur analisis kadar abu sebagai berikut: cawan yang akan digunakan dioven terlebih dahulu selama 30 menit pada suhu 100-105 ${ }^{\circ} \mathrm{C}$, kemudian didinginkan dalam desikator untuk menghilangkan uap air dan ditimbang (A). Sampel ditimbang sebanyak $2 \mathrm{~g}$ dalam cawan yang sudah dikeringkan (B) kemudian dibakar di atas nyala pembakar sampai tidak berasap dan dilanjutkan dengan pengabuan di dalam tanur bersuhu $550-600{ }^{\circ} \mathrm{C}$ sampai pengabuan sempurna. Sampel yang sudah diabukan didinginkan dalam desikator dan ditimbang (C). Tahap pembakaran dalam tanur diulangi sampai didapat bobot yang konstan. Kadar abu dihitung dengan rumus:

$$
\% \text { Kadar abu }=\frac{C-A}{B-A} \times 100 \%
$$

Keterangan :

A : berat cawan kosong dinyatakan dalam gram

$\mathrm{B}$ : berat cawan + sampel awal dinyatakan dalam gram

$\mathrm{C}$ : berat cawan + sampel kering dinyatakan dalam gram

\subsection{Analisis Kadar Lemak}

Analisis kadar lemak dilakukan dengan metode sokhlet [6]. Prinsipnya adalah lemak yang terdapat dalam sampel diekstrak dengan menggunakan pelarut lemak non polar.

Prosedur analisis kadar lemak sebagai berikut: labu lemak yang akan digunakan dioven selama 30 menit pada suhu 100-105 ${ }^{\circ} \mathrm{C}$, kemudian didinginkan dalam desikator untuk menghilangkan uap air dan ditimbang (A). Sampel ditimbang sebanyak 2 gram (B) lalu dibungkus dengan kertas saring, ditutup dengan kapas bebas lemak dan dimasukkan ke dalam alat ekstraksi sokhlet yang telah dihubungkan dengan labu lemak yang telah dioven dan diketahui bobotnya. Pelarut heksan atau pelarut lemak lain dituangkan sampai sampel terendam dan dilakukan refluks atau ektraksi lemak selama 5-6 jam atau sampai palarut lemak yang turun ke labu lemak berwarna jernih. Pelarut lemak yang telah digunakan, disuling dan ditampung setelah itu ekstrak lemak yang ada dalam labu lemak dikeringkan dalam oven bersuhu 100-105 ${ }^{\circ} \mathrm{C}$ selama 1 jam, lalu labu lemak didinginkan dalam desikator dan ditimbang (C). Tahap pengeringan labu lemak diulangi sampai diperoleh bobot yang konstan. Kadar lemak dihitung dengan rumus:

$$
\% \text { Lemak total }=\frac{(C-A) \times 100 \%}{B}
$$

Keterangan :

A : berat labu alas bulat kosong dinyatakan dalam gram

B : berat sampel dinyatakan dalam gram 
C : berat labu alas bulat dan lemak hasil ekstraksi dalam gram

\subsection{Analisis Kadar Protein}

Analisis kadar protein dilakukan dengan metode Kjeldahl [6]. Prinsipnya adalah oksidasi bahan-bahan berkarbon dan konversi nitrogen menjadi amonia oleh asam sulfat, selanjutnya amonia bereaksi dengan kelebihan asam membentuk amonium sulfat. Amonium sulfat yang terbentuk diuraikan dan larutan dijadikan basa dengan $\mathrm{NaOH}$. Amonia yang diuapkan akan diikat dengan asam borat. Nitrogen yang terkandung dalam larutan ditentukan jumlahnya dengan titrasi menggunakan larutan baku asam.

Prosedur analisis kadar protein sebagai berikut: sampel ditimbang sebanyak 0,1-0,5 g, dimasukkan ke dalam labu kjeldahl $100 \mathrm{ml}$, ditambahkan dengan $1 / 4$ buah tablet kjeltab, kemudian didekstruksi (pemanasan dalam keadaan mendidih) sampai larutan menjadi hijau jernih dan $\mathrm{SO}_{2}$ hilang. Larutan dibiarkan dingin dan dipindahkan ke labu 50 ml dan diencerkan dengan akuades sampai tanda tera, dimasukkan ke dalam alat destilasi, ditambahkan dengan 5-10 ml NaOH 30-33\% dan dilakukan destilasi. Destilat ditampung dalam larutan $10 \mathrm{ml}$ asam borat $3 \%$ dan beberapa tetes indikator (larutan bromcresol green 0,1\% dan 29 larutan metil merah 0,1\% dalam alkohol 95\% secara terpisah dan dicampurkan antara $10 \mathrm{ml}$ bromcresol green dengan $2 \mathrm{ml}$ metil merah) kemudian dititrasi dengan larutan $\mathrm{HCl} 0,02 \mathrm{~N}$ sampai larutan berubah warnanya menjadi merah muda. Kadar protein dihitung dengan rumus:

$$
\begin{aligned}
& \% \text { Protein }=\frac{(\mathrm{VA}-\mathrm{VB}) \mathrm{HCl} \times \mathrm{N} \mathrm{HCl} \times 14 \times 6,25 \times 100 \%}{W \times 1000} \\
& \text { Keterangan : } \\
& \mathrm{V}_{\mathrm{A}} \quad: \mathrm{ml} \mathrm{HCl} \text { untuk titrasi sampel } \\
& \mathrm{V}_{\mathrm{B}} \quad: \mathrm{ml} \mathrm{HCl} \text { untuk titrasi blangko } \\
& \mathrm{N} \text { : normalitas } \mathrm{HCl} \text { standar yang digunakan } \\
& 14,007 \text { : berat atom Nitrogen } \\
& 6,25 \text { : faktor konversi protein untuk ikan } \\
& \text { W : berat sampel dalam gram }
\end{aligned}
$$

\subsection{Analisis Total Plate Count (TPC)}

Prosedur perhitungan jumlah bakteri menurut [7], dengan modifikasi sebagai berikut :

Semua peralatan yang terdiri dari tabung reaksi berisi $9 \mathrm{ml} \mathrm{NaCl} \mathrm{0,9 \%} \mathrm{dan} \mathrm{cawan} \mathrm{petri}$ di sterilkan dengan menggunakan autoklaf dengan tekanan $1 \mathrm{~atm}$ selama 15 menit pada suhu $121^{\circ} \mathrm{C}$. Sebanyak 11,5 gr medium plate count agar (PCA) ditimbang, kemudian dimasukkan ke dalam tabung Erlennmeyer dan diberi aquades sebanyak $500 \mathrm{ml}$, setelah itu dihomogenkan dengan magnet putar. $\mathrm{pH}$ media diatur pada pH 7,0 selanjutnya direbus sampai agar larut dan disterilkan menggunakan autoklaf pada tekanan 1 atm dengan suhu $121{ }^{\circ} \mathrm{C}$ selama 15 menit. Sampel dihaluskan dan ditimbang 1 gr secara aseptis kemudian dimasukan kedalam 9 ml larutan $\mathrm{NaCl}$ 0,09\% steril sehingga diperoleh larutan dengan tingkat pengenceran 10-1. Dari pengenceran $10^{-1}$ dipipet $1 \mathrm{ml}$ ke tabung reaksi ke-2 kemudian diperoleh pengenceran $10^{-2}$, pengenceran dilakukan sampai pengenceran $10^{-3}$. Dari setiap pengenceran diambil $1 \mathrm{ml}$ pindahkan ke cawan petri steril yang telah diberi kode untuk setiap sampel pada tingkat pengenceran tertentu. Semua perlakuan dibuat duplo.

Medium PCA yang sudah dipanaskan kemudian didinginkan $45-50{ }^{\circ} \mathrm{C}$. Kedalam semua cawan petri dituangkan secara aseptis PCA sebanyak $15 \mathrm{ml}-20 \mathrm{ml}$. Setelah penuangan, cawan petri digoyang perlahanlahan sambil diputar 3 kali ke kiri dan kanan cawan petri, kemudian didinginkan sampai mengeras. setelah PCA padat dimasukan kedalam inkubator selama 24 jam pada suhu kamar $\left(37^{\circ} \mathrm{C}\right)$ dengan posisi terbalik. Setelah masa inkubasi berakhir, dilakukan perhitungan jumlah bakteri dan jumlah baktri yang diperoleh dikalikan dengan pengenceran. Perhitungan koloni menggunakan rumus sebagai berikut:

Total bakteri $(\mathrm{CFU})=$ jumlah koloni $\mathrm{x} 1$ /faktor pengenceran

\subsection{Analisis Data}

Data yang dianalisis dalam penelitian ini diolah secara deskriptif, dimana hasil yang 
diperoleh ditampilkan dalam bentuk histogram.

\section{HASIL DAN PEMBAHASAN}

\subsection{Kadar Air}

Hasil pengamatan terhadap kadar air ikan layang asin kering (Gambar 2) menunjukkan bahwa pada rak 1 adalah 25,58\%, rak 2 adalah 20,39\%, dan rak 3 adalah 17,80\%. Dimana kadar air terendah adalah perlakuan rak 3 yaitu 17,80\%. Rendahnya kadar air pada ikan layang asin kering hasil pengeringan pada rak 3 adalah disebabkan oleh suhu yang lebih tinggi pada tempat tersebut, dimana rak 3 berada di bagian atas dari ke 3 rak yang ada.

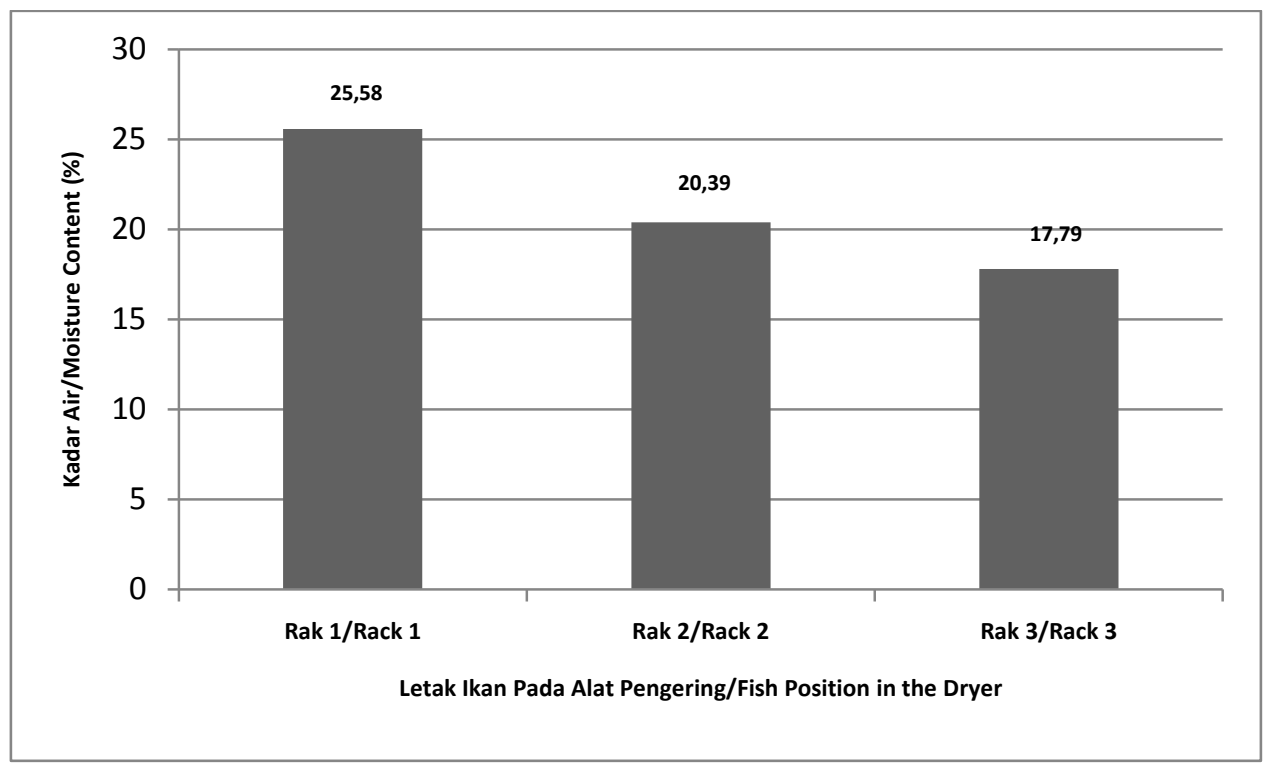

Gambar 2. Histogram Kadar Air Ikan Layang (Decapterus sp.) Asin Kering Fig. 2. Histogram of Moisture Content of Dried Salted Indian Scad (Decapterus sp.)

Kadar air ikan asin kering dipengaruhi oleh suhu dan lama pengeringan, semakin besar suhu dan lama waktu pengeringan maka kadar air ikan asin kering akan semakin kecil [8]. Hal ini juga sesuai dengan hasil penelitian [9] menyatakan semakin tinggi suhu pengeringan terhadap ikan kembung maka waktu pengeringan ikan semakin rendah, hasil penelitian menyatakn waktu pengeringan yang tercepat yaitu pada suhu $55^{\circ} \mathrm{C}$ dan yang terlama yaitu pada suhu $45^{\circ} \mathrm{C}$. Pada awal pengeringan kadar air dan laju pengeringannya tinggi, selanjutnya kadar air turun dengan cepat kemudian melandai dan sangat lambat saat menuju kadar air keseimbangan. Lama pengeringan semakin meningkat sejalan dengan menurunnya suhu pengeringan. [10] menyatakan semakin lama waktu pengeringan maka semakin rendah nilai kadar ikan asin kering. [11] menyatakan kadar air ikan teri (Stolephorus sp.) hasil pengeringan dengan sistim tertutup adalah $16,93 \%$, apabila dibandingkan dengan hasil penelitian ini dimana kadar air terendah adalah $17,80 \%$ adalah disebabkan perbedaan ukuran ikan dimana ikan teri ukurannya lebih kecil.

\subsection{Kadar Abu}

Nilai kadar abu ikan layang asin kering tertera pada Gambar 3. Hasil pengamatan menunjukkan kadar abu ikan asin kering yang dihasilkan berdasarkan peletakannya pada rak 1 , rak 2 dan rak 3 berturut-turut adalah 9,64\%, 9,69\% dan 7,71\%. Apabila dibandingkan dengan nilai kadar abu yang diperbolehkan SNI 27211:2009 dimana kadar abu tak larut asam 
diperbolehkan adalah $0,3 \%$ bukan berarti kadar abu ini sudah melebihi, karena kadar abu tak larut asam yang dimaksud adalah abu yang berasal dari pengotor yang bukan dari ikan. kadar abu pada penelitian ini adalah berupa bahan anorganik dan mineral yang berguna bagi tubuh.

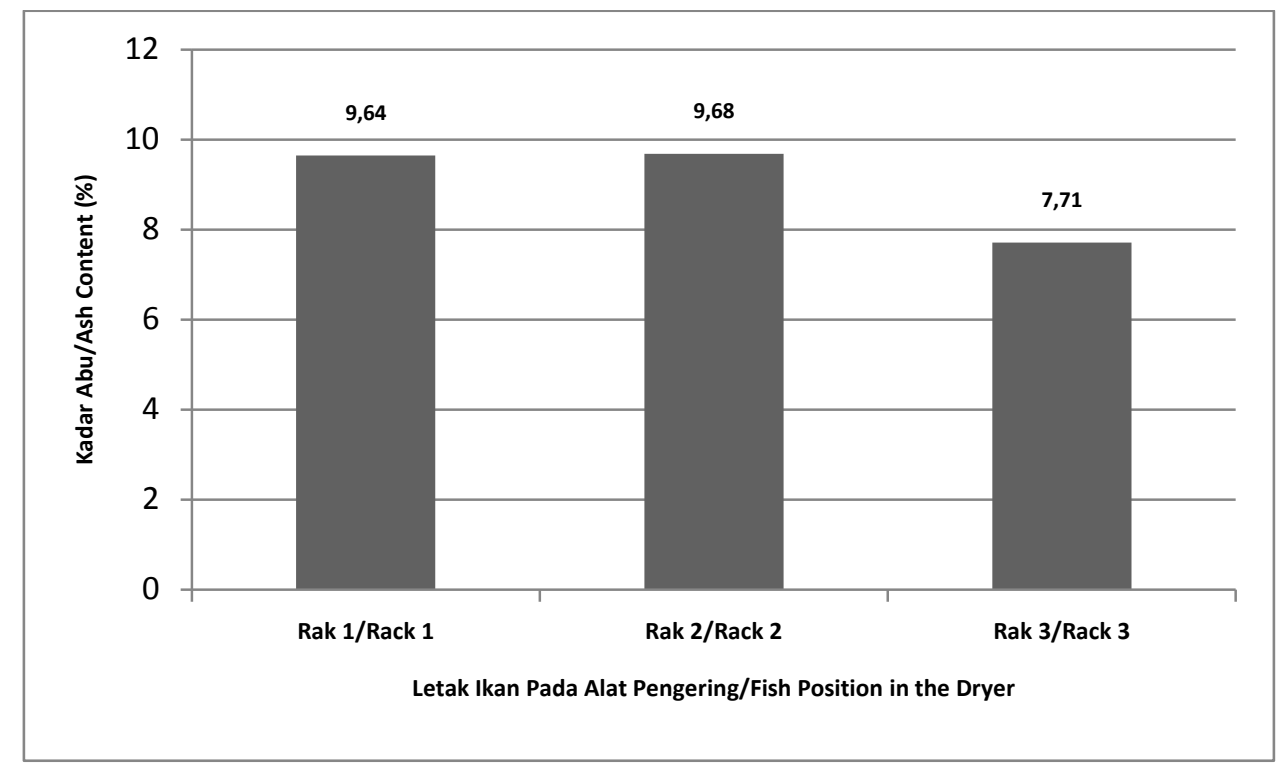

Gambar 3. Histogram Kadar Abu Ikan Layang Asin Kering Fig. 3. Histogram of Ash Content of Dried Salted Indian Scad

Apabila dibandingkan dengan hasil penelitian terdahulu oleh [12] menyatakan nilai kadar abu ikan asin kering beberapa jenis komersial berada pada kisaran 4,686,72\% dan [13] menyatakan berkisar antara 4,56-9,98\%, maka kadar abu ikan layang asin kering ini masih berada pada kisaran hasil penelitian mereka. Penentuan kadar abu total dapat digunakan untuk berbagai tujuan, antara lain untuk mementukan baik atau tidaknya suatu pengolahan, mengetahui jenis bahan yang digunakan dan sebagai penentu parameter nilai gizi suatu bahan makanan.

\subsection{Kadar Lemak}

Hasil pengamatan terhadap kadar lemak ikan layang asin kering tertera pada Gambar 4. Kadar lemak hasil pengeringan pada Rak1, Rak 2 dan Rak 3 berturut-turut adalah 8,08, 11,40, dan 15,16. Kadar lemak tertinggi terdapat pada ikan layang asin kering yang dikeringkan pada Rak 3 dan berbanding terbalik dengan kadar air. Hal ini menunjukkan semakin kecil kadar air maka kadar lemak semakin besar karena ketika air berkurang baik lemak maupun protein akan meningkat. Kadar lemak pada ikan asin kering rentan terhadap ketengikan, oleh karena itu perlu penanganan lebih lanjut seperti pengemasan kedap udara. 


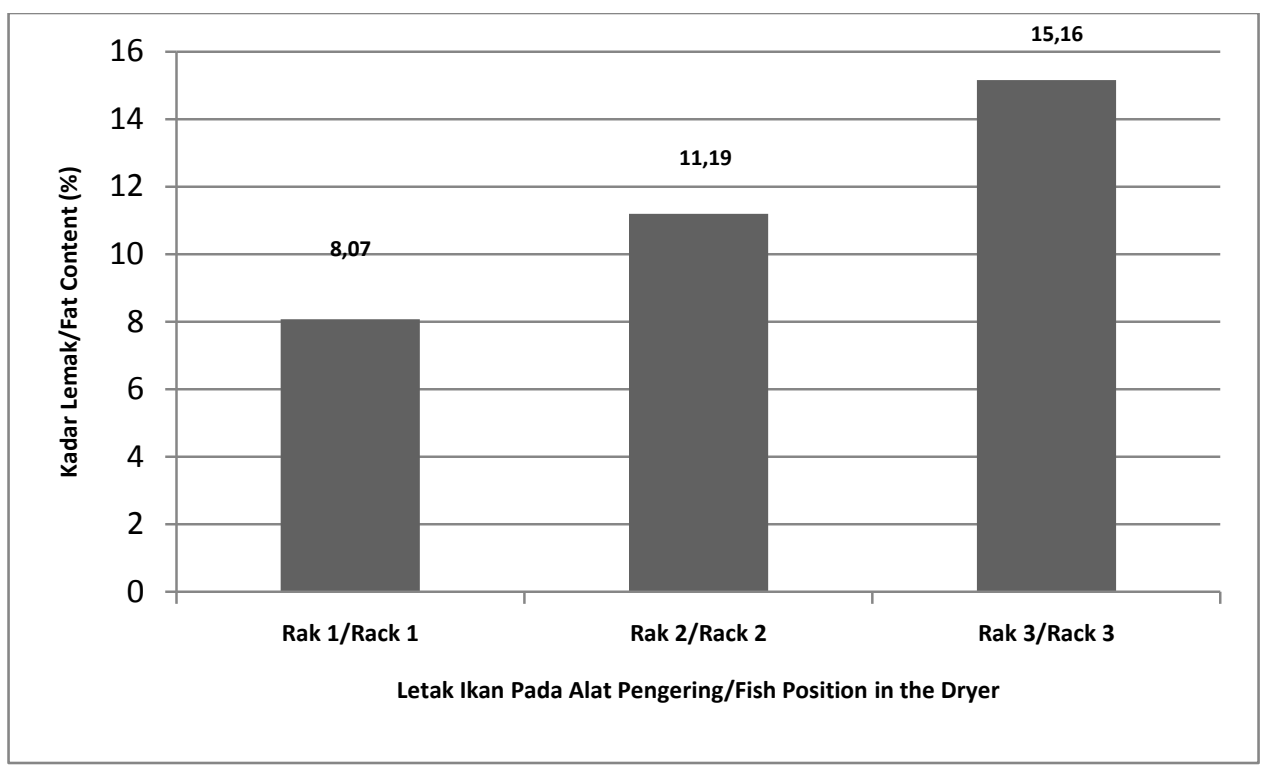

Gambar 4. Histogram Kadar Lemak Ikan Layang Asin Kering

Fig. 4. Histogram of Fat Content Of Dried Salted Indian Scad

Apabila dilihat kadar lemak ikan layang asin kering ini cukup tinggi, akan tetapi masih lebih rendah dari hasil penelitian terdahulu oleh [14] menyatakan kadar lemak ikan asin kering jenis lakerda mempunyai kadar lemak $17,39 \%$, hasil penelitian mereka juga menyatakan bahwa kadar lemak cenderung mengalami kenaikan setelah proses pengeringan. Komponen nutrisi seperti protein, lemak dan abu cenderung mengalami kenaikan disebabkan oleh pengurangan air selama pengeringan [15; 16]

\subsection{Kadar Protein}

Hasil pengamatan terhadap ikan layang asin kering menunjukkan bahwa kadar protein dari ikan layang asin kering pada Rak 1, Rak 2 dan Rak 3 berturutturut adalah 53,73\%, 58,10\%, dan 59,1\% (Gambar 5). Dimana kadar protein tertinggi adalah perlakuan Rak 3 yaitu $59,11 \%$. Tingginya kadar protein pada ikan layang asin kering pada Rak 3 disebabkan oleh tingginya pengurangan air pada lokasi tersebut, sehingga persentase padatan menjadi semakin besar. 


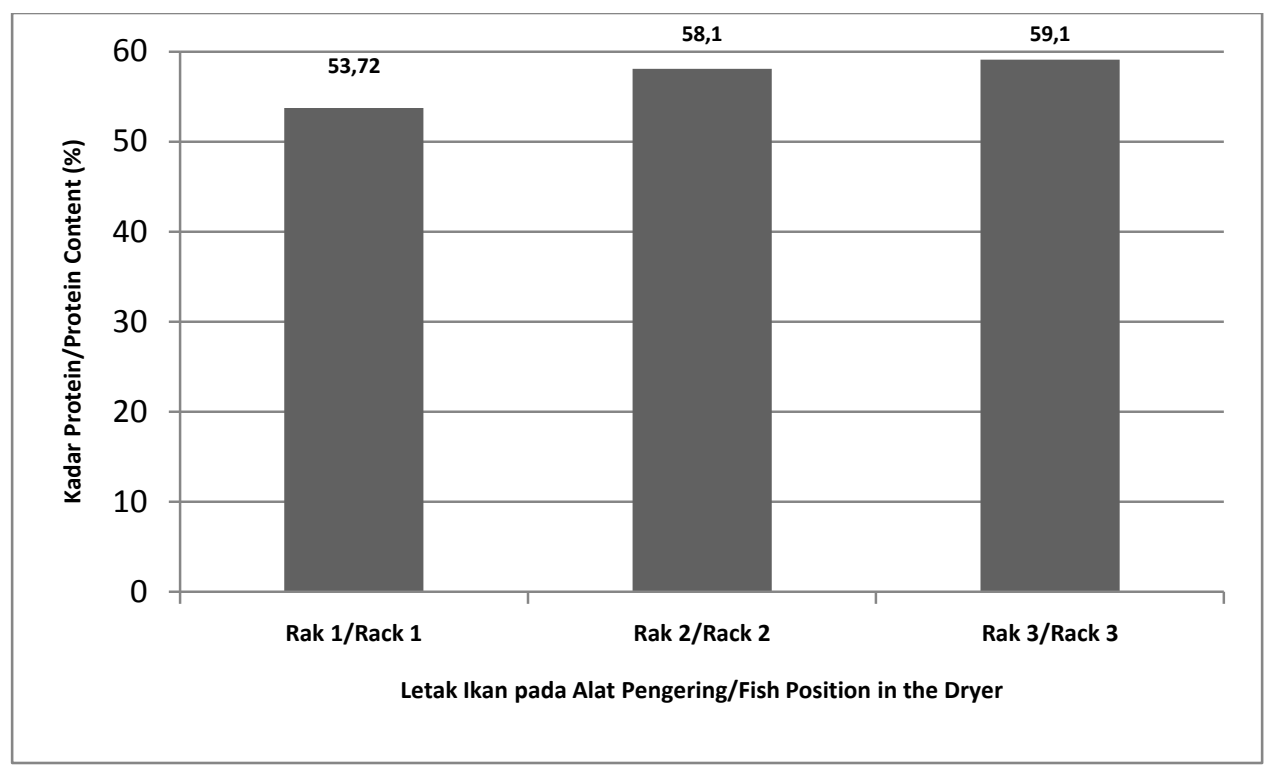

Gambar 5. Histogram Kadar Protein Ikan Layang Asin Kering.

Fig. 5. Histogram of Protein Content of Dried Salted Indian Scad

[17] menyatakan nilai kadar protein pada ikan lele kering meningkat dari rata-rata ikan lele segar $18,40 \%$ meningkat menjadi ratarata 51,20\%. Apabila dibandingkan dengan penelitian tersebut maka kadar protein ikan layang asin kering mempunyai kadar protein yang lebih tinggi yaitu 59,11\%. [8] menyatakan nilai kadar protein ikan sepat asin kering tertinggi adalah 49,43\%.

\subsection{Nilai TPC}

Gambar 6 menunjukkan nilai TPC ikan layang asin kering yang dihasilkan dari alat pengering sinar matahari tertutup pada Rak 1, Rak 2 dan Rak 3 berturut-turut 2,73 $\log \mathrm{x}$ $\mathrm{CFU} / \mathrm{g}$ atau $5,4 \times 10^{2} \mathrm{CFU} / \mathrm{g}, 2,74 \mathrm{logx} \mathrm{CFU} / \mathrm{g}$ atau $5,5 \times 10^{2} \mathrm{CFU} / \mathrm{g}$, dan 2,74 logx CFU/gr atau $5,9 \times 10^{2} \mathrm{CFU} / \mathrm{gr}$. Berdasarkan syarat mutu ikan asin kering (SNI, 2009) untuk Angka Lempeng Total (ALT) atau Total Plate Count (TPC) adalah maksimal 1,0 x $10^{5}$. 


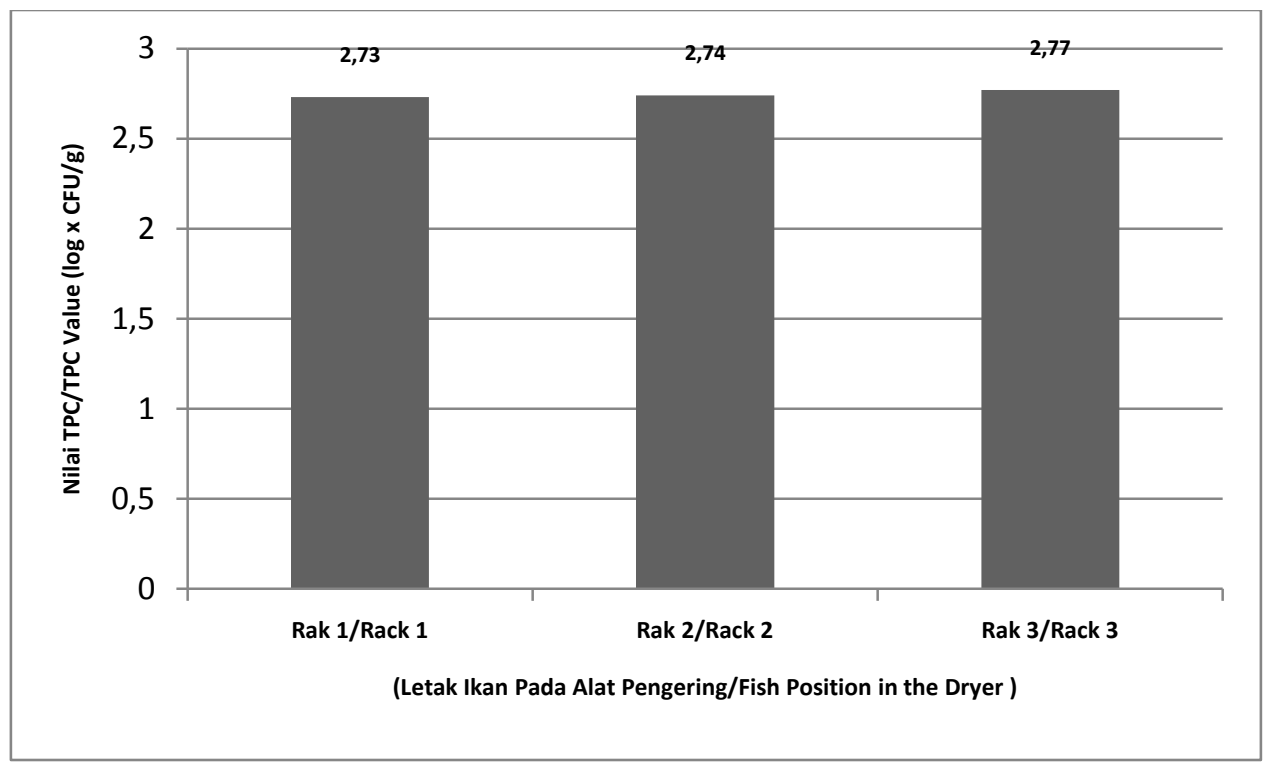

Gambar 6. Histogram Nilai TPC Ikan Layang Asin Kering Fig. 6. Histogram of TPC Value of Dried Salted Indian Scad

[11] menyatakan nilai TPC ikan teri (Stolephorus sp.) kering adalah 6,92 x $10^{2}$ $\mathrm{CFU} / \mathrm{g}$ atau 2,84 $\log \mathrm{CFU} / \mathrm{g}$. Nilai ini lebih besar dari rata-rata nilai TPC ikan layang asin kering. Hal ini menunjukkan bahwa penanganan sebelum pengeringan dengan cara penggaraman akan mempengaruhi nilai TPC ikan asin kering.

\section{KESIMPULAN.}

Hasil uji proksimat menunjukkan bahwa alat pengering matahari sistim tertutup menghasilkan ikan layang asin kering yang berkualitas

baik dimana nilai kadar air, kadar abu, kadar lemak dan dadar protein masih berada pada standar yang disyaratkan oleh SNI. Tempat terbaik untuk meletakkan ikan pada alat pengering adalah pada Rak 3 hal ini ditunjukkan oleh kadar air yang rendah.

Nilai TPC ikan layang asin kering hasil pengeringan menggunakan sistim pengering tertutup menunjukkan hasil yang baik, dimana nilai TPC masih berada pada batas nilai yang di syaratkan oleh SNI.

\section{DAFTAR PUSTAKA}

[1] Weber M. and Beaufort LF. 1931. The fishes of the Indo-Australian Archipelago. E.J. Leiden, 6: 194-201.

[2] Bala BK. And Mondol MR. 2001. Experimental investigation onsolar drying of fish using solar tunnel dryer. Drying Technology, 19(2): 427436.

[3] Basri DF., Bakar NF., Fudholi A., Ruslan MH. and Saroeun I. 2015. Comparison of selected metals content in cambodian striped snakehead fish (Channa striata) using solar drying system and open sun drying. Journal of Environmental and Public Health, 1-6.

[4] Nguyen MV., Jonsson A. and Arason S. 2012. Effect of freeze drying on quality of desalted tusk fish. Asian Journal of Food and Agro-Industry, 5(05): 388-394.

[5] Ratti C. 2001. Hot air and freeze-drying of highvalue foods: a review. Journal of Food Engineering, 49: 311-319.

[6] [AOAC]. 2005. Official methods of analysis of the association of analytical chemist. Virginia USA: association of official analytical chemist, Inc. 
[7] Fardiaz S. 2001. Analisis Mikrobiologi Pangan. Jakarta. PT Raja Grafindo Persada.

[8] Riansyah A., Supriadi A., dan Nopianti R. 2013. Pengaruh perbedaan suhu dan waktu pengeringan terhadap karakteristikikan asin sepat siam (Trichogaster pectoralis) dengan menggunakan oven. Fishtech 2(1): 53-68.

[9] Hawa LC., Sumardi, dan Sari EP. 2009. Penentuan karakteristik pengeringan lapi tik pengeringan lapisan tipis ikan kembung kembung (Rastrelliger sp.). Jurnal Teknologi Pertanian, 10(3): 153-161.

[10] Tuyu A., Onibala H. dan Makapedua DM. 2014. Studi lama pengeringan ikan selar (Selaroides sp.) asin dihubungkan dengan kadar air dan nilai organoleptik. Jurnal Media Teknologi Hasil Perikanan, 2(2): 20-26.

[11] Savitri I K., Silaban B. dan Sormin RBD. 2018. Mutu produk teri (Stolephorus sp.) kering pulau Buru dengan metode pengering surya tertutup. Jurnal Pengolahan Hasil Perikanan Indonesia, 21(3): 543-548.

[12] Siddique MA., Mojumder P. and Zamal H. 2012. Proximate composition of three comercially available marine dry fishes (Harpodon nehereus,
Johnius dussumieri and Lepturacanthus savala). American Journal of Food Technology, 7(7): 429436.

[13] Gheyasudin S., Rahman AM. and Kamal M. 1980. Nutritive quality of some of the commercial marine fishes of Bangladesh. Bangladesh Journal of Agriculture, 5: 1-38.

[14] Ormanci HB. and Colakoglu FA. 2015. Nutritional and sensory properties of salted fish product, lakerda. Cogen Food and Agriculture, 1(1): 1-13.

[15] Bras, A., \& Costa, R. (2010). Influence of brine salting prior to pickle salting in the manufacturing of various salted-dried fish species. Journal of Food Engineering , 100 (3), 490-495.

[16] Chaijan M. 2011. Physicochemical changes of tilapia (Oreochromis niloticus) muscle during salting. Food Chemistry, 129(3): 1201-1210.

[17] Yuarni D., Kadirman dan Jamaluddin. 2015. Laju perubahan kadar air, kadar protein dan uji organoleptik ikan lele asin menggunakan alat pengering kabinet (cabinet dryer) dengan suhu terkontrol. Jurnal Pendidikan Teknologi Pertanian, 1: 12-21. 